\title{
PLEISTOCENE EDIBLE DORMICE (RODENTIA MAMMALIA) FROM SLOVENIA, AND THEIR RELATIONS TO THE PRESENT DAY GLIS GLIS (LINNAEUS 1766)
}

\author{
PLEISTOCENSKI POLHI (RODENTIA MAMMALIA) IZ SLOVENIJE \\ IN NJIHOVA SORODNOST S SEDANJIM POLHOM GLIS GLIS \\ (LINNAEUS 1766)
}

\author{
Jean-Pierre AGUILAR ${ }^{1} \&$ Jacques MICHAUX ${ }^{1}$
}

\begin{abstract}
UDC 599.323.2(497.4)
Jean-Pierre Aguilar \& Jacques Michaux: Pleistocene edible dormice (Rodentia Mammalia) from Slovenia, and their relations to the present day Glis glis (Linnaeus 1766)

A Pleistocene new material of dormice (Genus Glis) is described. Three morphological species are recognized on the basis of size and morphology of the teeth: Glis sackdillingensis Heller, 1930, Glis mihevci nov. sp., and Glis perkoi nov. sp. The two new species, larger than G. sackdillingensis, are morphologically less evolved than the present day Glis glis of Slovenia, which has larger teeth.
\end{abstract}

Keywords: rodents, Glis, Pleistocene, recent, Slovenia.
Izvleček UDK 599.323.2(497.4) Jean-Pierre Aguilar \& Jacques Michaux: Pleistocenski polhi (Rodentia Mammalia) iz Slovenije in njihova sorodnost $s$ sedanjim polhom Glis glis (Linnaeus 1766)

Opisali smo nov kostni material pleistocenskih polhov (Rod Glis). Na osnovi morfologije zob smo ločili tri različne morfološke vrste: Glis sackdillingensis Heller, 1930, Glis mihevci nov. sp., in Glis perkoi nov. sp. Dve na novo določeni vrsti sta večji kot $G$. sackdillingensis in sta morfološko manj razviti kot je sedanji Glis glis v Sloveniji, ki ima tudi večje zobe.

Ključne besede: glodalci, polh, pleistocen, sedanji, Slovenija.

\section{INTRODUCTION}

In relation with the French - Slovenian Program PROTEUS for the study of the Karst, several deposits were discovered which provided abundant remains, mainly teeth, of a dormouse referred to the genus Glis. A unique species, Glis glis (Linnaeus 1766)] - the edible dormouse also known as the fat dormouse - represents this Palearctic genus today (Fig. 1A). This species is emblematic of the Slovenian wildlife and is also hunted. Aside the regional interest of this new material, its morphological analysis is worth of interest for several reasons. First, a large amount of data is available among others, for the German and Slovenian dormice - the type locality of the species is located in the part of Slovenia called Carniola (Storch 1978) -, second, there is the synthesis by Holden
(2005) on the family Gliridae, and third because a mitochondrial phylogeography of the edible dormouse in the western Palearctic region has recently been published (Hürner et al. 2010).

If only one extant species is recognized in the genus Glis, many more species names have been proposed for interpreting the geographical variation within it. They have been rejected as synonyms of the type species (Holden 2005). The genus Glis is also documented in the European Neogene and two extinct species have been described: Glis minor Kowalski, 1956, and Glis sackdillingensis Heller, 1930, which are recognized by the size and the shape of their teeth. Few recent studies bared on fossil material except for the Polish dormice (Daoud 1993).

\footnotetext{
${ }^{1}$ Institut des Sciences de l'Evolution (UMR 5554 - CNRS) Université Montpellier 2, CC 064, Place Eugène Bataillon, F-34095 Montpellier cedex 5, e-mails: jean-pierre.aguilar@univ-montp2.fr, jacques-jules.michaux@univ-montp2.fr

Received/Prejeto: 25.5.2010
} 


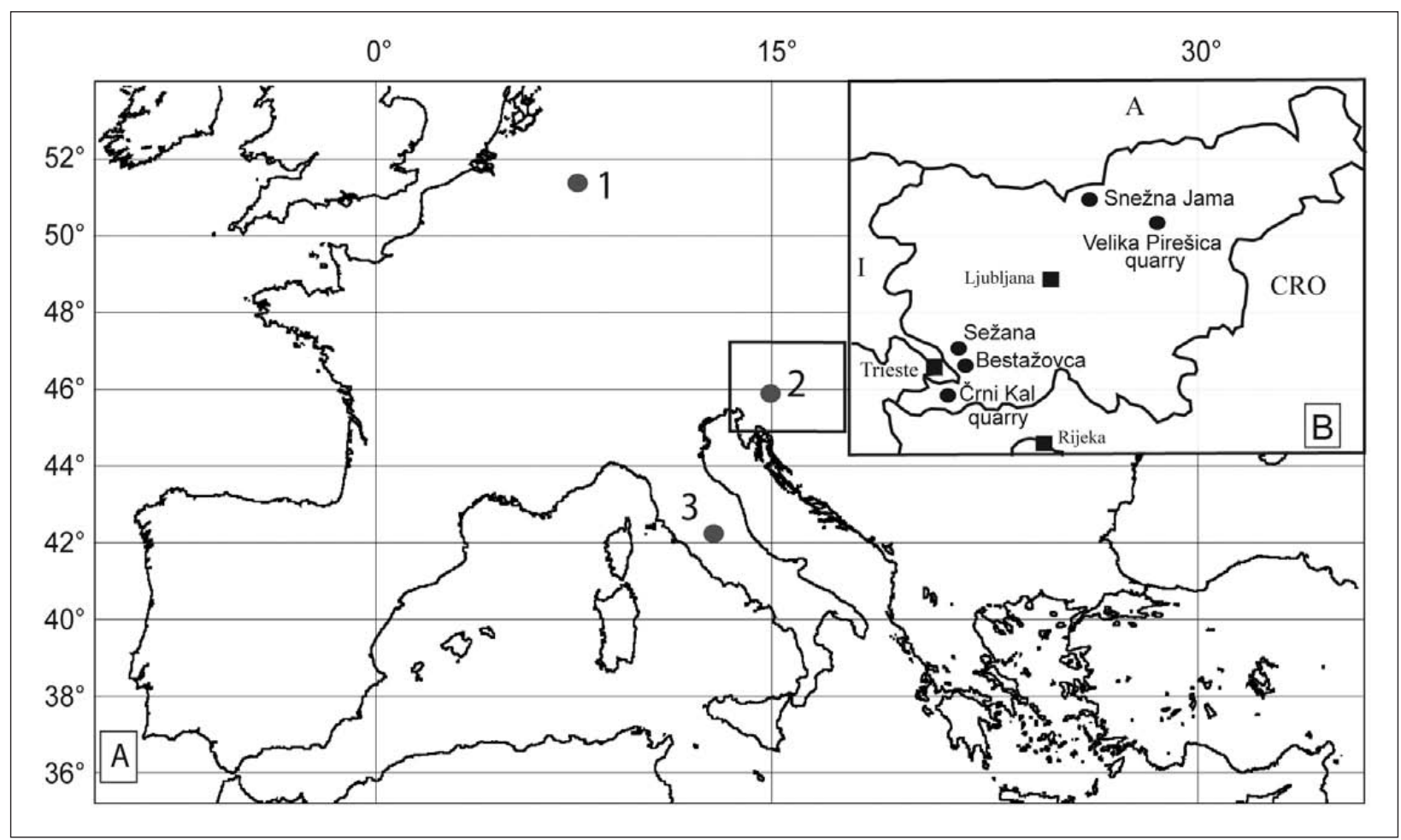

Fig. 1: A - Type areas of Glis subspecies: 1, G. g. glis (Linnaeus 1766); 2: G. g. postus Montagu, 1923; G. g. italicus Barett-Hamilton, 1898 (from Storch, 1978). B - Map of Slovenia, with the position of the localities of discovered micromammal fauna.

The abundant new fossil material collected in Slovenia provides a good opportunity to address the following questions: 1) how much these new populations differ from already described fossil species and from the pres- ent populations, and 2) is it possible that tooth morphology does help illustrating even partly some conclusions of the recent mitochondrial phylogeographical analysis of Hürner et al. (2010)?

\section{MATERIAL AND METHODS}

All the deposits that provided the studied fossil dormice are Pleistocene (Aguilar et al. 1998, 2001). One of them, Velika Pirešica, is characterized by the abundance of dental and skeletal remains, the dormouse representing more than $95 \%$ of the small mammal fauna specimens. The localities are distributed into two distinct areas: the karst area in the western part of Slovenia (Črni Kal Quarry, Sežana and Bestažovca), and central Slovenia (Velika Pirešica). The present day edible dormouse from Slovenia is used for metric and morphologic comparison. Among the samples, there are specimens collected by Mr. Marjan Perko in the forested area of Postojna and Planina (Western Slovenia) during the hunting season of the year 1999. Measurements of these specimens are given as supplementary data. Other specimens came from regurgitation pellets of birds of prey collected by A. Mihevc in the areas of Postojna and Sežana (Western Slovenia), and in the Snežna Jama cave (North-Eastern Slovenia) (Fig. 1B). One specimen of dormouse determined as Glis glis italicus from a Tyto alba pellet collected in 1998 by Mr. A. Nappi of Naples near Petina (Salerno province, Campania, Southern Italy) has been included in the study. Their measurements are summarized in Tab. 1 \& Fig. 2.

The nomenclature used for the description of teeth is after Daams (1981, 1999) (Fig. 3). Measurements, given in millimetres, were carried out under a Wild stereomicroscope, using a Leica device for $2 \mathrm{D}$ orthogonal measurements.

The material is partly held in part in the collections of the University of Montpellier 2 and in the Karst Research Institute of Postojna (Slovenia). 


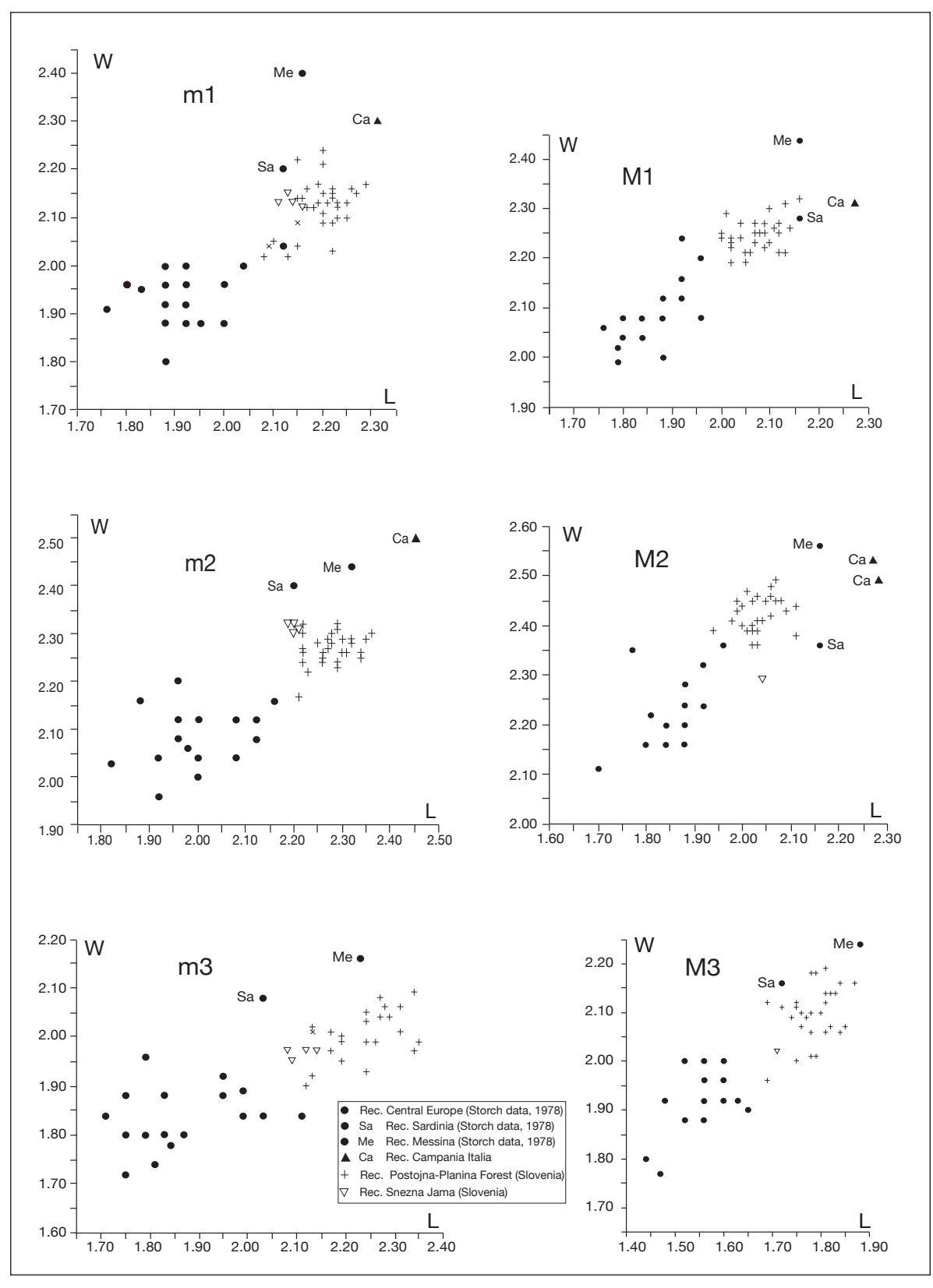

Fig. 2: $L x W$ distribution diagrams for recent Glis glis samples (M, upper and $m$, lower molars).

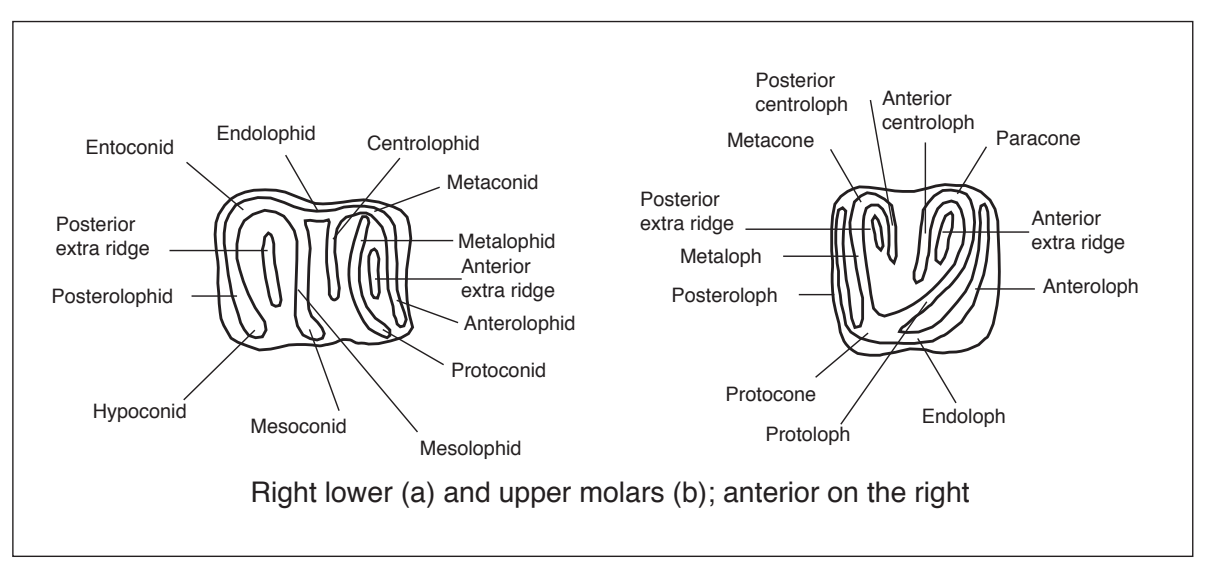

Fig. 3: Nomenclature of Gliridae for cheek teeth (after Daams 1981). 
Tab. 1: Glis glis from Slovenia: tooth measurements ( $L x W$; in $\mathrm{mm}$ ). Abbreviations: $n$, number of specimens, min, minimum, max, maximum. The teeth of the left and right tooth rows of the specimen from Campania have been added.

\begin{tabular}{|c|c|c|c|c|c|c|c|c|}
\hline & \multirow[t]{2}{*}{ Localities } & \multirow[b]{2}{*}{$\mathrm{n}$} & \multicolumn{3}{|c|}{ Length } & \multicolumn{3}{|c|}{ Width } \\
\hline & & & $\min$ & mean. & $\max$ & $\min$ & mean. & $\max$ \\
\hline \multirow[t]{2}{*}{$\mathrm{d} 4$} & Slovenia & 19 & 1.21 & 1.31 & 1.37 & 1.14 & 1.23 & 1.28 \\
\hline & Campania & 2 & & $1.38-1.45$ & & & $1.34-1.40$ & \\
\hline p4 & & 6 & 1.43 & 1.50 & 1.63 & 1.42 & 1.49 & 1.52 \\
\hline \multirow[t]{2}{*}{$\mathrm{m} 1$} & Slovenia & 34 & 2.08 & 2.19 & 2.28 & 2.02 & 2.12 & 2.23 \\
\hline & Campania & 1 & & 2.31 & & & 2.30 & \\
\hline \multirow[t]{2}{*}{$\mathrm{m} 2$} & Slovenia & 33 & 2.20 & 2.27 & 2.36 & 2.17 & 2.27 & 2.32 \\
\hline & Campania & 1 & & 2.45 & & & 2.50 & \\
\hline $\mathrm{m} 3$ & Slovenia & 30 & 2.14 & 2.27 & 2.36 & 1.91 & 2.00 & 2.09 \\
\hline \multirow[t]{2}{*}{ D4 } & Slovenia & 1 & & 1.17 & & & 1.40 & \\
\hline & Campania & 2 & & $1.41-1.49$ & & & $1.49-1.61$ & \\
\hline $\mathrm{P} 4$ & Slovenia & 6 & 1.50 & 1.55 & 1.61 & 1.73 & 1.79 & 1.84 \\
\hline \multirow[t]{2}{*}{ M1 } & Slovenia & 31 & 1.98 & 2.07 & 2.15 & 2.12 & 2.24 & 2.32 \\
\hline & Campania & 1 & & 2.27 & & & 2.31 & \\
\hline \multirow[t]{2}{*}{ M2 } & Slovenia & 31 & 1.98 & 2.04 & 2.11 & 2.29 & 242 & 2.48 \\
\hline & Campania & 2 & & $2.27-2.28$ & & & $2.49-2.53$ & \\
\hline M3 & Slovenia & 31 & 1.71 & 1.78 & 1.84 & 1.98 & 2.09 & 2.18 \\
\hline
\end{tabular}

\section{THE EXTINCT GLIS OF SLOVENIA}

The present study dealing with fossil material represented by isolated teeth, it has been considered that in a preliminary stage of the analysis it would be better that distinct populations receive specific names as done below.

\section{Genus Glis Brisson, 1762}

Type species: Glis glis (Linnaeus 1766).

\section{Glis mihevci nov. sp.}

(Fig. 4b-4i \& 5b-5t)

Holotype: an isolated tooth M2 dex. (1.84 x 2.14) VLP n ${ }^{\circ} 268$ (Fig. 5g).

Type locality: Velika Pirešica, Slovenia

Other localities: Črni Kal 2.

Figured paratypes: 3 p4, $2 \mathrm{~m} 1,1 \mathrm{~m} 2,2 \mathrm{~m} 3,5 \mathrm{P} 4$, $5 \mathrm{M} 1,3 \mathrm{M} 2,5 \mathrm{M} 3$.

Derivatio nominis: In honour of Dr. Andrej Mihevc for his efficient help during field works and who discovered the Velika Pirešica locality.
Diagnosis: Middle-sized of Glis with Protocone and posteroloph, and protoloph - metaloph connected to distinct. Anteroplophid and protoconid connected to distinct.

Differential diagnosis: Glis mihevci nov. sp. differs from Glis glis postus by the occurrence of primitive morphological characters, finer sized ridges and cusps, and the merging of protocone with hypocone. Glis mihevci nov. sp. is intermediate in size between extant edible dormouse, Glis glis germanicus, and G. glis postus, which are larger, and Glis sackdillingensis and Glis minor, which are smaller. Glis mihevci nov. sp. is smaller than Glis perkoi nov. sp. (Črni Kal and Sežana) despite similarity in tooth morphology.

Material and measurements: nearly a thousand of teeth was collected, and measurements are given in Tab. 2 \& Fig. 6. 


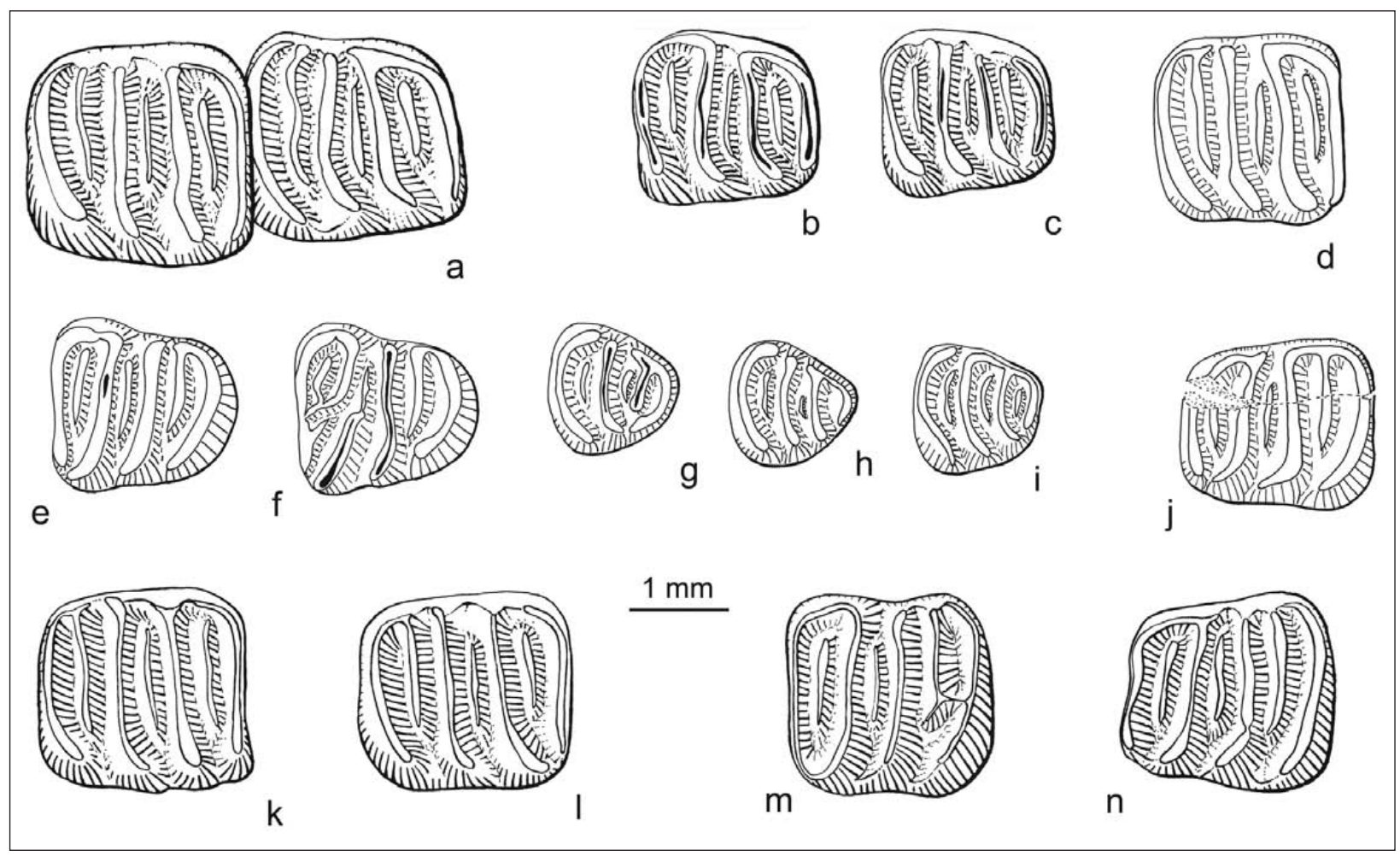

Fig 4: Lower molars of fossil and recent Glis from Slovenia.

4a: Recent Glis glis postus: $m 1-m 2$ dex. [m1 (2.21 $\times 2.18), m 2(2.29 \times 2.30)]$ PTN n ${ }^{\circ} 15$.

4b-4i: Glis mihevci nov. sp. from Velika Pirešica locality: $4 b, m 1$ dex. (1.92 x 1.89) VLP $n^{\circ} 1 ; 4 c, m 1$ dex. (1.78 $\left.x 1.78\right)$ VLP $n^{\circ}$ 2; 4 , $m 2$ dext. $\left(1.93 x\right.$ 1.91) VLP $n^{\circ}$ 52; $4 e, m 3$ sen. (1.91 x 1.73) VLP $n^{\circ} 102 ; 4 f, m 3$ sen. (1.88 $\left.x 1.80\right) V L P n^{\circ} 126 ; 4 g, p 4$ dext. (1.36 x 1.37) VLP $n^{\circ} 167$; 4 h, p4 dext. (1.32 x 1.30) VLP $n^{\circ} 172$; $4 i$, p4 dext. (1.33 x 1.31) VLP $n^{\circ} 191$.

4j: Glis sackdillingensis from Črni Kal 3 locality: $m 1$ sen. $(2.00 x 1,71)$ CRK $3 n^{\circ} 14$.

4k-4m: Glis perkoi nov. sp. from Črni Kal Quarry localities: $4 k, m 2$ dex. (2.20 x 2.12) CRK $3 n^{\circ}$ 5; $4 l, m 2$ dex. (2.20 $\left.x 2.12\right) C R K 3 n^{\circ} 6$; $4 m, m 2$ sen. $(2.12 \times 2.09) C R K 4 n^{\circ} 2$.

4n: Glis perkoi nov. sp. from Sežana locality: $m 1$ sen. (2.18 $x 2.13) \operatorname{SZN} n^{\circ} 2$.

\section{Velika Pirešica locality}

Description:

The lower and upper premolars and deciduous molars are not described due to their relatively low number and above all because of the variability of their crown pattern as illustrated in Fig. 4g-4i \& 5p-5t.

Lower molars:

$\mathrm{m} 1$. The outline of the crown is roughly rectangular with the anterior half of the tooth narrower than the posterior one. There are five lophids and two extra ridges. The anterolophid is usually not connected to the protoconid (only ca. $5 \%$ of teeth with these lophids connected). The centrolophid varies in length, usually unconnected to the metaconid, it may be connected to the latter in a few cases (9\%). The talonid is not always closed lingually. The posterior extra ridge is always well developed and starting from the lingual side. This $\mathrm{m} 1$ has two roots. $\mathrm{m} 2$. The outline is rectangular with anterior and posterior halves of nearly equal width. This molar shows the same morphological characteristics as the $\mathrm{m} 1$. The $\mathrm{m} 2$ has three roots, the anterior root being split into two, the lingual root being much smaller than the labial one. This character is easily observed only on well-preserved teeth with long roots.

$\mathrm{m} 3$. This molar has a narrow posterior half, this part of the tooth being lingually reduced, otherwise, morphology as in $\mathrm{m} 2$.

Upper molars:

M1. Its shape is almost square with the posterior half a little less wide than the front one. It presents five major lophs and two major extra ridges. The anteroloph is isolated as well as is the centroloph, which lingually develops a strong mesocone. Some specimens (ca 6\%) show small extra ridges between centroloph and protoloph and between centroloph and metaloph. The protocone is connected to posteroloph in ca $85 \%$ of cases. 


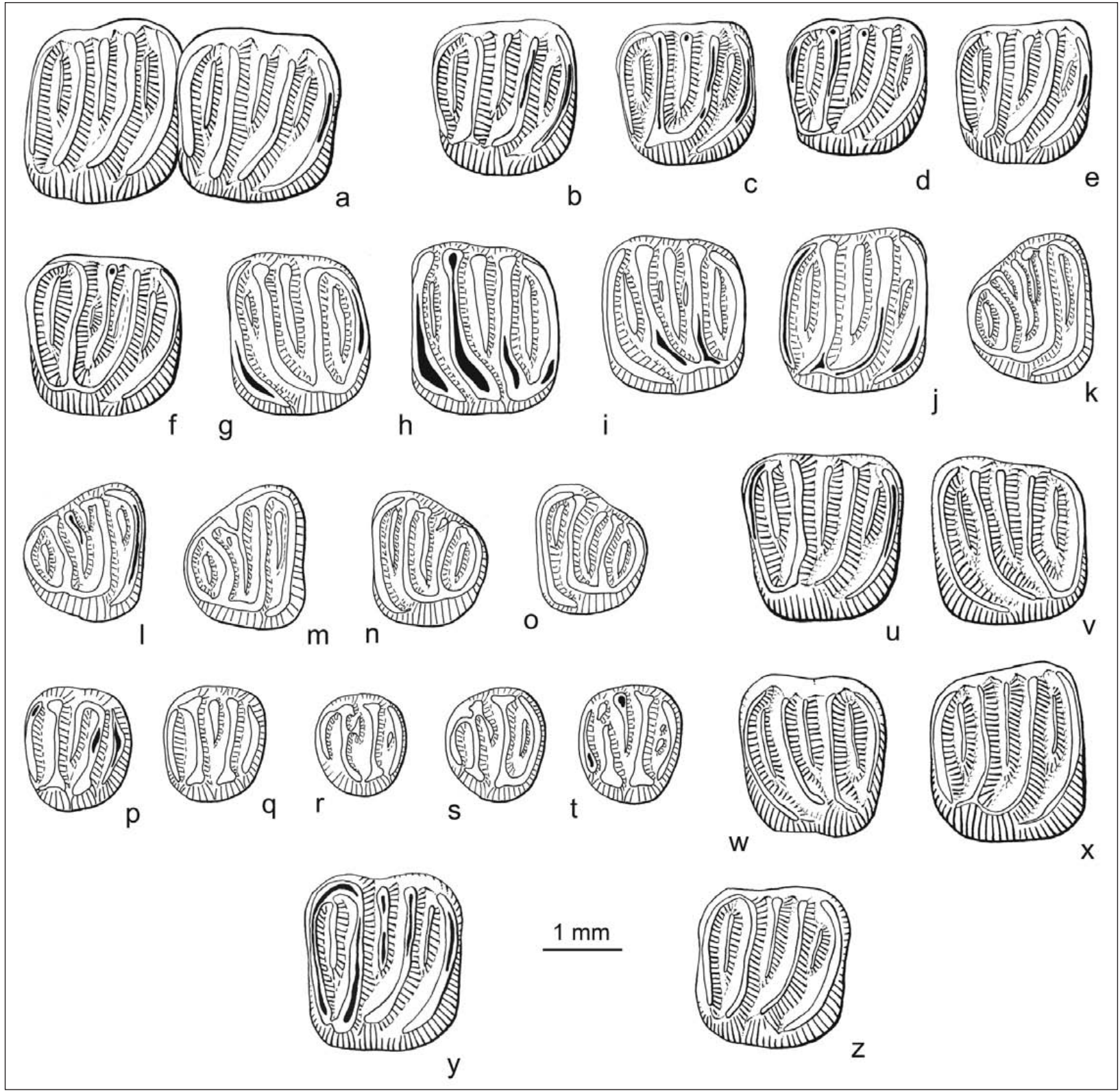

Fig. 5: Upper molars of fossil and recent Glis from Slovenia.

5a: Recent Glis glis postus : M1-M2 dex. [ M1 (2.10 x 2.27), M2 (2.02 x 2.43)] PTN $n^{\circ} 15$.

5b-5t: Glis mihevci nov. sp. from Velika Pirešica locality: 5b, M1 dex. (1.79 x 1.92) VLP $n^{\circ} 218$; 5 c, M1 dex. (1.85 x 1.98) VLP $n^{\circ} 231$; 5d, M1 dext. (1.80 x 1.86) VLP $n^{\circ}$ 232; 5e, M1 dex. (1.74 x 1.92) VLP $n^{\circ} 233 ; 5 f, M 1$ dex. (2.00 x 2.06) VLP $n^{\circ} 220 ; 5 g, M 2$ sen. (1.84 x 2.14) VLP $n^{\circ} 268$ Holotype; 5h, M2 sen. (1.89 x 2.15) VLP $n^{\circ} 269 ; 5 i, M 2$ sen. (1.84 x 2,07) VLP $n^{\circ} 272 ; 5 j, M 2$ dex. (1.89x 2.10) $V L P n^{\circ} 275 ; 5 k, M 3 \operatorname{dex}$. (1.62 x 1.91) VLP $n^{\circ} 317$; $5 l, M 3$ dex. (1.56 x 1.76) VLP $n^{\circ} 318 ; 5 m, M 3$ dex. (1.56 x 1.82) VLP $n^{\circ} 319$; $5 n, M 3$ sen. (1.49 x 1.76) VLP $n^{\circ} 320 ; 50, M 3$ sen. (1.43 x 1.75) VLP $n^{\circ} 324 ; 5 p, P 4 \operatorname{dex}$. (1.38 x 1.59) VLP $n^{\circ} 377 ; 5 q P 4$ dex. (1.32 $x$

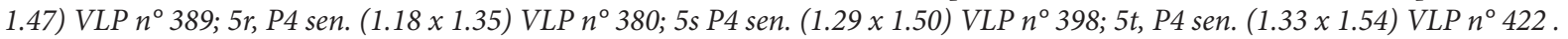

5u-5x: Glis perkoi nov. sp. from Črni Kal Quarry localities: 5u, M1 dex. (2.07 x 2.20) CRK $3 n^{\circ} 10 ; 5 v$, M2 sen. (1.95 x 2.13) CRK $3 n^{\circ}$ 12; $5 w, M 1$ sen. (1.90 x 2.12) CRK $4 n^{\circ} 4$; $5 x$, M2 dex. (2.02 $\left.x 2.34\right) C R K 4 n^{\circ} 7$.

$5 y$ \& 5z: Glis perkoi nov. sp. from Sežana locality: 5y, M1 dex. (2.03 x 2.28) Holotype, SZN n 10; $5 z, M 1$ dex. (1.99 x 2.21$)$ SZN $n^{\circ} 11$.

Protoloph and metaloph are separated on half of the specimens.
M2. This molar is usually wider than long. Anteroloph and centroloph are isolated. Small extra ridges are 


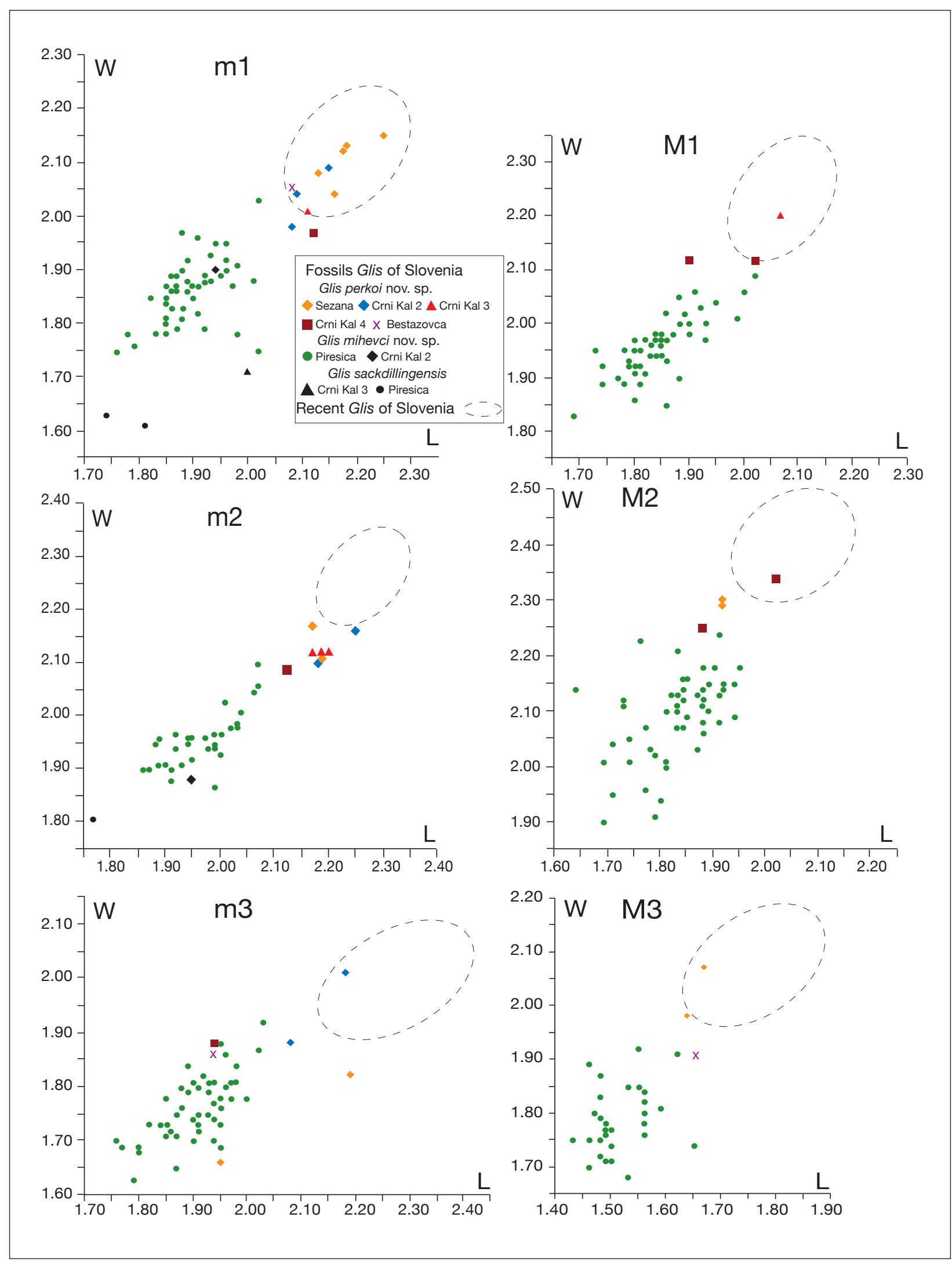

Fig. 6: $L x W$ distribution diagrams for fossil Glis glis samples (M, upper and $m$, lower molars). 
Tab. 2: Tooth measurements ( $L \times W$; in $\mathrm{mm}$ ) of fossil material. $n$, number of specimens, min, minimum, max, maximum.

\begin{tabular}{|c|c|c|c|c|c|c|c|c|}
\hline \multirow{2}{*}{\multicolumn{2}{|c|}{$\begin{array}{l}\text { Species / Localities } \\
\text { Glis mihevci nov. sp. }\end{array}$}} & \multicolumn{5}{|c|}{ Length } & \multicolumn{2}{|c|}{ Width } \\
\hline & & $\mathrm{n}$ & min. & mean & max. & min. & mean & $\max$ \\
\hline \multicolumn{9}{|c|}{ Velika Pirešica } \\
\hline $\mathrm{d} 4$ & & 16 & 1.09 & 1.20 & 1.30 & 0.98 & 1.08 & 1.17 \\
\hline $\mathrm{p} 4$ & - & 50 & 1.14 & 1.32 & 1.40 & 1.17 & 1.32 & 1.45 \\
\hline $\mathrm{m} 1$ & - & 50 & 1.76 & 1.89 & 1.98 & 1.75 & 1.86 & 1.96 \\
\hline $\mathrm{m} 2$ & - & 50 & 1.77 & 1.96 & 2.07 & 1.81 & 1.95 & 2.10 \\
\hline $\mathrm{m} 3$ & - & 50 & 1.76 & 1.91 & 2.03 & 1.63 & 1.76 & 1.92 \\
\hline D4 & - & 10 & 1.09 & 1.19 & 1.31 & 1.23 & 1.29 & 1.41 \\
\hline P4 & - & 50 & 1.18 & 1.32 & 1.43 & 1.35 & 1.53 & 1.66 \\
\hline M1 & - & 50 & 1.73 & 1.85 & 2.02 & 1.85 & 1.96 & 2.09 \\
\hline $\mathrm{M} 2$ & - & 50 & 1.64 & 1.83 & 1.95 & 1.90 & 2.09 & 2.24 \\
\hline M3 & - & 50 & 1.90 & 2.09 & 2.24 & 1.42 & 1.52 & 1.65 \\
\hline \multicolumn{9}{|c|}{ Glis perkoi nov. sp. } \\
\hline $\mathrm{p} 4$ & Sežana & 1 & & 1.55 & & & 1.49 & \\
\hline \multirow[t]{5}{*}{$\mathrm{m} 1$} & Sežana & 4 & 2.13 & 2.18 & 2.25 & 2.04 & 2.10 & 2.15 \\
\hline & Črni Kal 2 & 3 & 2.08 & 2.11 & 2.15 & 1.98 & 2.04 & 2.16 \\
\hline & Črni Kal 3 & 1 & & 2.11 & & & 2.01 & \\
\hline & Črni Kal 4 & 1 & & 2.12 & & & 1.97 & \\
\hline & Bestažovca & 1 & & 2.08 & & & 2.05 & \\
\hline \multirow[t]{4}{*}{$\underline{\mathrm{m} 2}$} & Sežana & 2 & 2.17 & & 2.19 & 2.11 & & 2.17 \\
\hline & Črni Kal 2 & 2 & 2.18 & & 2.25 & 2.10 & & 2.16 \\
\hline & Črni Kal 3 & 3 & 2.17 & 2.19 & 2.20 & 2.12 & 2.12 & 2.12 \\
\hline & Črni Kal 4 & 1 & 2.12 & & & & 2.09 & \\
\hline \multirow[t]{4}{*}{$\mathrm{m} 3$} & Sežana & 2 & 1.95 & & 2.19 & 1.66 & & 1.82 \\
\hline & Črni Kal 2 & 2 & 2.08 & & 2.18 & 1.88 & & 2.01 \\
\hline & Črni Kal 4 & 1 & & 1.94 & & & 1.88 & \\
\hline & Bestažovca & 1 & & 1.94 & & & 1.86 & \\
\hline \multirow[t]{2}{*}{ D4 } & Sežana & 1 & & 1.51 & & & 1.74 & \\
\hline & Črni Kal 2 & 1 & & 1.45 & & & 1.68 & \\
\hline P4 & Črni Kal 3 & 1 & & 1.58 & & & 1.76 & \\
\hline \multirow[t]{3}{*}{ M1 } & Sežana & 5 & 1.95 & 2.00 & 2.04 & 2.21 & 2.23 & 2.28 \\
\hline & Črni Kal 3 & 1 & & 2.07 & & & 2.20 & \\
\hline & Črni Kal 4 & 2 & 1.90 & & 2.02 & 2.12 & & 2.12 \\
\hline \multirow[t]{3}{*}{ M2 } & Sežana & 2 & 1.92 & & 1.92 & 2.29 & & 2.30 \\
\hline & Črni Kal 3 & 2 & 1.95 & & 1.97 & 2.13 & & 2.26 \\
\hline & Črni Kal 4 & 2 & 1.88 & & 2.02 & 2.25 & & 2.34 \\
\hline \multirow[t]{3}{*}{ M3 } & Sežana & 2 & 1.64 & & 1.67 & 1.98 & & 2.07 \\
\hline & Črni Kal 3 & 1 & & 1.78 & & & 2.00 & \\
\hline & Bestažovca & 1 & & 1.66 & & & 1.91 & \\
\hline
\end{tabular}


sometimes present (ca 10\%). The connection between posteroloph and protocone is lacking in a third of the sample. Protoloph and metaloph are separated on half of the specimens.

M3. This molar is reduced postero-laterally. A unique centroloph is present a few molars (ca 7\%). On other specimens, there are two centrolophs, the posterior centroloph post being the longest in ca $71 \%$ of specimens. In a quarter of the teeth, both centrolophs are connected together. About a third of specimens, there are additional extra ridges, mostly between the posterior centroloph and the metaloph, which are very small or even under the form of an enamel bud.

All molars are three-rooted.

\section{Črni Kal 2 locality}

Material and dimensions: $1 \mathrm{~m} 1$ (1.94 x 1.90), $1 \mathrm{~m} 2$ (1.95 x 1.88) CRK n ${ }^{\circ} 1$ and 2.

Discussion:

Differences with the extant Slovenian dormouse also referred to Glis glis postus Montagu, 1923 are summarized in Tab. 3 and addressed in the final discussion. The characters used to recognize a difference of degree of morphological evolution have been based on a comparison with extinct Miocene glirids (Pseudodryomys, Peridyromys, Miodyromys, among many others), which provide the primitive states of characters used in the present description. Fig. 3 provides the nomenclature used for glirids according Daams (1981) and illustrates these character states. More information about the phylogeny of the family based in part on molar morphology can be found in Daams (1999). The derived states on molars are defined in the present study as follows: 1) posteroloph not connected to metaloph: derived, 2) metaloph and protoloph not connected: derived, 3) anterolophid not labially connected to metalophid : derived. These three characters are found in all studied fossil populations.
Glis perkoi nov. sp.

(Fig. $4 \mathrm{n} \& 5 \mathrm{u}-5 \mathrm{z}$ )

Holotype: an isolated tooth M1 dex. (2.03 x 2.28) SZN n ${ }^{\circ} 10$ (Fig. 5y).

Type locality: Sežana, Slovenia

Other localities: Črni Kal localities 2, 3, 4, Bestažovca?

Figured paratypes: $1 \mathrm{~m} 1,3 \mathrm{M} 1,2 \mathrm{M} 2$

Derivatio nominis: In honour of Mr. Marjan Perko to whom we owe the studied skulls of the recent Slovenian edible dormouse.

Diagnosis: Large-sized of Glis with protocone and posteroloph merged or separated. Anterolophid and protoconid merged or separated.

Differential diagnosis: Glis perkoi nov. sp. differs from both Glis glis germanicus and Glis glis postus by the occurrence of more primitive characters, weaker ridges and cusps, with the merge of the protocone into the posteroloph. Glis perkoi nov. sp. is similar in dental morphology to Glis mihevci nov. sp. of Velika Pirešica, but teeth are smaller.

\section{Sežana locality}

Material and maesurements: isolated teeth Tab. 2 \& Fig. 6.

\section{Črni Kal localities}

Several fissure fillings have been investigated in the Črni Kal quarry where localities 2, 3 and 4 are considered contemporaneous.

Material and dimensions: Tab. 2 \& Fig. 6

Črni kal 2 (19 isolated teeth), Črni Kal 3 (13 isolated teeth), Črni Kal 4 (9 isolated teeth).

Discussion:

The few specimens from Sežana, Črni Kal 2, 3, and 4 show morphological features already present in the population of Velika Pirešica. Teeth are larger. The stage in evolution is lower than in the present Slovenian Glis.

Tab. 3.

\begin{tabular}{l|l|l}
\hline Morphology & Recent Glis glis postus (Slovenia) & Glis mihevci nov. sp. \\
\hline Crests & Thick & Slender \\
\hline Cusps & More individualized, larger & Less individualized, smaller \\
\hline Connection anterolophid - protoconid & Not connected, wide « area labialis » & $\begin{array}{l}\text { Sometime connected, narrow to wide } \\
\text { " area labialis » (m1, m2) }\end{array}$ \\
\hline Centrolophid & Always large & Sometime smaller \\
\hline Connection protocone - posteroloph & Always widely separated & $\begin{array}{l}\text { 85\% of specimens (M1, M2) with } \\
\text { connection }\end{array}$ \\
\hline Connection protoloph - metaloph & Always well separated & $\begin{array}{l}\text { Half of specimens (M1, M2) with a } \\
\text { connection }\end{array}$ \\
\hline
\end{tabular}


Glis sackdillingensis Heller, 1930

Velika Pirešica locality

Material and dimensions: $2 \mathrm{~m} 1(1,81 \times 1,61 ; 1,74$ x 1,63); $1 \mathrm{~m} 2(1,77 \times 1,81) ; 1 \mathrm{M} 1(1,69 \times 1,83) \mathrm{VLP}^{\circ}$ 427-430.

Črni Kal 3 locality (Fig. 4j)

$1 \mathrm{M} / 1(2,00 \times 1,71)$ CRK $3 \mathrm{n}^{\circ} 14$.
Discussion

These few teeth are similar to the teeth of Glis sacskdillingensis from the Polish localities (Kowalski 1963). They differ from the other fossil teeth from Slovenia by their small size (Fig. 6), however the sample being very small, the determination is only based on $\mathrm{m} 1$ and $\mathrm{m} 2$.

\section{SUPPLEMENTARY DATA}

Tab. 4: Tooth measurements ( $L \times W$; in $m m$ ) taken on extant skulls and mandibles of the edible dormouse Glis glis postus trapped in Slovenia, B- Glis glis italicus. Abbreviations: Post., Postojna; Sn. Ja., Snežna jama.

\begin{tabular}{|c|c|c|c|c|c|c|c|c|c|c|}
\hline Specimens & d4 & p4 & m1 & m2 & m3 & D4 & P4 & M1 & M2 & M3 \\
\hline Post. $n^{\circ} 1$ & $1.32 \times 1.26$ & & $2.20 \times 2.14$ & $2.24 \times 2.28$ & $2.30 \times 2.01$ & & $1.51 \times 1.73$ & $2.01 \times 2.22$ & $1.98 \times 2.42$ & $1.77 \times 2.10$ \\
\hline Post. $n^{\circ} 2$ & $1.30 \times 1.25$ & & $2.20 \times 2.08$ & $2.27 \times 2.27$ & $2.34 \times 2.05$ & $1.17 \times 1.40$ & $1.54 \times 1.78$ & $2.11 \times 2.22$ & $2.06 \times 2.45$ & $1.83 \times 2.10$ \\
\hline Post. $n^{\circ} 3$ & $1.35 \times 1.26$ & & $2.20 \times 2.11$ & $2.29 \times 2.24$ & $2.24 \times 1.99$ & & & $2.09 \times 2.24$ & $2.05 \times 2.41$ & $1.82 \times 2.11$ \\
\hline Post. $n^{\circ} 4$ & $1.31 \times 1.21$ & & $2.21 \times 2.15$ & $2.31 \times 2.30$ & $2.34 \times 1.95$ & & & $2.08 \times 2.21$ & $2.03 \times 2.39$ & $1.76 \times 2.05$ \\
\hline Post. $n^{\circ} 5$ & & & $2.20 \times 2.13$ & $2.28 \times 2.26$ & $2.35 \times 2.06$ & & & $2.10 \times 2.25$ & $2.09 \times 2.44$ & $1.84 \times 2.11$ \\
\hline Post. $n^{\circ} 6$ & $1.31 \times 1.22$ & & $2.19 \times 2.14$ & $2.25 \times 2.27$ & $2.29 \times 2.04$ & & & $2.01 \times 2.23$ & $2.01 \times 2.40$ & $1.78 \times 2.10$ \\
\hline Post. $n^{\circ} 7$ & $1.21 \times 1.14$ & & $2.13 \times 2.05$ & $2.24 \times 2.26$ & $2.22 \times 1.99$ & & & $2.04 \times 2.22$ & $2.01 \times 2.45$ & $1.74 \times 2.12$ \\
\hline Post. $n^{\circ} 8$ & & & $2.21 \times 2.11$ & $2.36 \times 2.30$ & $2.36 \times 2.09$ & & & $2.09 \times 2.26$ & $2.04 \times 2.48$ & $1.83 \times 2.14$ \\
\hline Post. $n^{\circ} 9$ & $1.29 \times 1.17$ & & $2.23 \times 2.10$ & $2.31 \times 2.26$ & $2.18 \times 2.02$ & & & $2.13 \times 2.24$ & $2.03 \times 2.41$ & $1.76 \times 2.07$ \\
\hline Post. $n^{\circ} 10$ & & $1.47 \times 1.42$ & $2.19 \times 2.15$ & $2.23 \times 2.24$ & $2.18 \times 1.91$ & & $1.50 \times 1.78$ & $2.07 \times 2.24$ & $2.01 \times 2.40$ & $1.72 \times 1.98$ \\
\hline Post. $n^{\circ} 11$ & $1.31 \times 1.25$ & & $2.18 \times 2.23$ & $2.25 \times 2.31$ & $2.29 \times 2.02$ & & & $2.02 \times 2.27$ & $2.01 \times 2.42$ & $1.72 \times 2.12$ \\
\hline Post. $n^{\circ} 12$ & $1.37 \times 1.27$ & & $2.28 \times 2.16$ & $2.34 \times 2.26$ & $2.24 \times 1.95$ & & & $2.07 \times 2.29$ & $2.04 \times 2.42$ & $1.79 \times 2.04$ \\
\hline Post. $n^{\circ} 13$ & & $1.63 \times 1.52$ & $2.21 \times 2.15$ & $2.29 \times 2.30$ & $2.38 \times 2.00$ & & $1.61 \times 1.80$ & $2.06 \times 2.26$ & $2.11 \times 2.41$ & $1.84 \times 2.18$ \\
\hline Post. $n^{\circ} 14$ & $1.35 \times 1.26$ & & $2.26 \times 2.15$ & $2.32 \times 2.28$ & $2.29 \times 2.03$ & & & $2.15 \times 2.32$ & $2.07 \times 2.48$ & $1.79 \times 2.18$ \\
\hline Post. $n^{\circ} 15$ & $1.32 \times 1.28$ & & $2.21 \times 2.18$ & $2.29 \times 2.30$ & $2.29 \times 1.99$ & & $1.61 \times 1.84$ & $2.10 \times 2.27$ & $2.02 \times 2.43$ & $1.81 \times 2.08$ \\
\hline Sn. Ja n ${ }^{\circ} 1$ & & $1.43 \times 1.50$ & $2.13 \times 2.13$ & $2.21 \times 2.32$ & $2.18 \times 1.97$ & & & & & \\
\hline Sn. Ja. n² & & $1.47 \times 1.50$ & $2.15 \times 2.14$ & $2.20 \times 2.31$ & $2.14 \times 1.96$ & & & $1.98 \times 2.12$ & $2.04 \times 2.29$ & $1.71 \times 2.02$ \\
\hline \multirow[t]{2}{*}{ Sežana } & & & $2.08 \times 2.02$ & $2.21 \times 2.17$ & & & & & & \\
\hline & & & $2.13 \times 2.02$ & & & & & & & \\
\hline
\end{tabular}

\section{DISCUSSION}

The edible dormouse is a member of the European fauna and many species or subspecies names have been proposed from phenotypic traits such as coat colour, skull length, size ... (Storch 1978; Kryštufek 1999). The rather few metric available data about teeth make comparisons with fossil material difficult. Though our data are also limited, clear differences of size and of molar morphol- ogy have been illustrated between fossil populations and extent ones that allow some hypotheses.

According tooth size, by comparison with populations from Poland (Kowalski 1963), Germany and Croatia (Storch 1978), the present day dormouse from Slovenia is larger. These data confirm the size difference already observed between the two sub-species 
G. g. postus Montagu, 1923 and G. g. germanicus Violani and Zava, 1995. The dental dimensions from these dormice are also smaller than those of the dormouse from Messina (Italy) and of G. g. italicus Barrett-Hamilton, 1898. Tooth size and crown morphology of fossil populations from Slovenia differ from the -present populations of dormouse and allow separating the populations from Velika Pirešica (Slovenia) on one side, from the populations from Sežana, Črni Kal 2,3,4, Bestažovca on the other side this latter being larger (Fig. 6). There are also several morphological characters of the teeth that are indicative of a lesser degree of morphological evolution for these fossil populations: especially transversal crests define synclines that are opened on the lingual side on upper molars and labial side on lower ones. Such a fact is not in contradiction with the dating of the faunas. The faunas from Sežana, Črni Kal 2, 3, 4 have been referred to the Middle Pleistocene (Aguilar et al. 1998, 2001). The age of Velika Pirešica is more difficult to determine because the extreme scarcity of easily determinable vole teeth.

A clear pattern comes out from these comparisons: all fossil populations are characterized by teeth smaller than the ones of the present day dormouse from the same area. The distribution of tooth size for the fossil populations referred to Glis mihevci nov. sp. and Glis perkoi nov. $\mathrm{sp}$. is more or less similar to the one corresponding to the present day Slovenian and Central European dormice, but only a little displaced towards smaller sizes, and only a few much smaller teeth are present which are referred to Glis sackdillingensis. One conclusion is the recognition of a weak morphological evolution through time even if the dating accuracy of the localities is still weak. A second conclusion is the recognition of tooth size change during the Pleistocene even if any polarity can be demonstrated. Another conclusion is the larger size of the present day dormouse that may likely indicate a late Pleistocene substitution event in the fauna of Slovenia. A last conclusion is the occurrence in the Pleistocene of another species of dormouse, Glis sackdillingensis, which is known in the European since the Pliocene (Aguilar et al. 1986).

How to interpret the present morphological analysis under the light of both the review of Holden (2005) on the family Gliridae, and the recent published mitochondrial phylogeography of Glis glis? It has been here considered that it would be better to give a specific status to populations of teeth that present distinct characteristics as usually done in Palaeontology than to use a subspecific status, which is in use for present day geographic divisions of species. Independently of such a decision, the documentation on extent and extinct populations of the Slovenian dormouse illustrates distinctions based on tooth mean sizes during the Pleistocene and an increase of size with the end of the Pleistocene. As it is not possible to refute the co-occurrence of the two species G. perkoi and G. mihevci (two lower molars in the locality Črni Kal 2), such events may be consecutive to climatic oscillations that affect the distribution of the animals in an area that is partly under the influence of the Mediterranean sea and of Alpine and Central Europe. It would be worth of interest to compare present day dormice from different geographic parts of Slovenia and to extend such analyses to nearby countries.

\section{ACKNOWLEDGMENTS}

Contribution ISE-M 2011 - 2016 (CNRS-UMR 5554)

We thank Ms. Katarina Krivic and Mr. Mihevc An-

drej, Marjan Perko, Armando Nappi, for assistance in the collect of fossils and current dormice.
The word was supported by the Programme Proteus $n^{\circ} 97011$ (Mammifères fossils et karst). 


\section{REFERENCES}

Aguilar, J.-P., M. Calvet \& J. Michaux, 1986 : Description des rongeurs pliocènes de la faune du MontHélène (Pyrénées-Orientales), nouveau jalon entre les faunes de Perpignan (Serrat-d'en-Vacquer) et de Sète.- Palaeovertebrata, 16, 3, 127-144.

Aguilar, J.-P., Crochet, J.-Y., Krivic, K., Marandat, B., Michaux, J., Mihevc, A., Sigé, B. \& S. Šebela, 1998: Pleistocene small Mammals from some karstic Fillings of Slovenia. Preliminary results.- Acta Carsologica, 27, 2, 141-150.

Aguilar, J. -P., Crochet, J.-Y., Michaux, J., Mihevc, A. \& M. Paunovič, 2001: The small vertebrate fauna (Rodents, Insectivores, and Reptiles) of Sandalja 1A (Istria, Croatia).- Acta Carsologica, 30, 1, 115-124.

Daams, R., 1981: The dental pattern of the Dormice Dryomys, Myomimus, Microdyromys and Peridyromys. Utrecht micropaleontological bulletins.- Special publication, 3, 1-113.

Daams, R., 1999: Family Gliridae.- In: Rössner, G. \& K. Heissig, K. (eds.) The Miocene Land Mammals of Europe. F. Pfeil, pp. 301-318, München.

Daoud, A., 1993. Evolution of Gliridae (Rodentia, Mammalia) in the Pliocene and Quaternary of Poland.Acta Zoologica Cracoviensia, 36, 2, 199-231.
Holden, M.E., 2005: Family Gliridae.- In: D. E. Wilson \& D. M. Reeder (eds.) Mammal Species of the World a Taxonomic and Geographic Reference. Johns Hopkins University Press, 819-841, Baltimore.

Hürner, H., Krystufek, B., Sara, M., Ribas, M.A., Ruch, T., Sommer, R., Ivashkina, V. \& J.-R. Michaux, 2010: Mitochondrial phylogeography of the edible dormouse (Glis glis) in the western Palearctic region.Journal of Mammalogy, 91, 1, 233-242.

Kowalski, K., 1963: The Pliocene and Pleistocene Gliridae (Mam. Rod.) from Poland.- Acta Zoologica Cracoviensia, 8, 14, 533-567.

Kryštufek, B., 1999: Glis glis (Linnaeus, 1766).- In: Mitchell-Jones, A.J. et al. (eds.) The atlas of European mammals. A. D. Poyser, Ltd., pp. 294-295, London.

Storch, G., 1978: Glis glis (Linnaeus, 1766).- In: Handbuch der Säugetiere Europas. Band 1, Nagetiere 1. Akademische Verlagsgesellschaft, pp. 243-258, Wiesbaden. 